\title{
EFFICACY OF SELECTED GRANULAR INSECTICIDES FOR THE CON- TROL OF MAIZE-STEM BORER (CHILO PARTELLUS) (LEPIDOPTERA: PYRALIDAE)
}

KNC Gunewardena* and SRK Madugalla

Field Crops Research and Development Institute, Maha Illuppallama, Sri Lanka

Accepted: 1 December, 2010

\begin{abstract}
Stem borer (Chilo partellus) is the most destructive pest of maize causing considerable yield losses especially during yala season. At present the pest is managed through whorl application of insecticide granules or foliar spraying of liquid formulations of insecticides. However, effective control of the pest cannot be expected from liquid formulations due to practical difficulties in the spraying especially at the mature stages of the crop. Hence, investigations were carried out in two consecutive yala seasons in 2008 and 2009 to study the efficacy of granular type insecticides against the stem borer. The maize hybrid variety Sampath was used. Four insecticides were tested along with an untreated control. Insecticides were applied twice as whorl applications at 2 week interval.
\end{abstract}

The percentage stem borer damage in plots treated with Diazinon 5G, Fipronil 0.3G and Thiocyclam hydrogen oxalate 4G found to be $<8 \%$ as compared to $>35 \%$ damage in untreated control. Larval population and severity of stem borer damage were also significantly low in Diazinon 5G, Fipronil 0.3G and Thiocyclam hydrogen oxalate 4G treated plots during both seasons over the control. The percentage seed yield in Diazinon 5G, Fipronil 0.3G and Thiocyclam hydrogen oxalate 4G treated plots found to be $52-91 \%$ and $28-44 \%$ higher than the untreated control during yala 2008 and 2009 respectively. Therefore, Fipronil $0.3 \mathrm{G}$ and Thiocyclam hydrogen oxalate $0.4 \mathrm{G}$ can be recommended in addition to the present recommendation of Diazinon 5G for the control of stem borer in maize.

Key words: Chilo partellus, Granular, Insecticides, Maize, Stem borer

\section{INTRODUCTION}

Maize (Zea mays L) is one of the most important cereal crops grown in Sri Lanka. The area under maize in Sri Lanka is about 51,000 ha and production is about $112,000 \mathrm{t}$ in 2008 (AgStat, 2009). In terms of area and production, it ranks second after rice among the cereal grains (Hindagala, 1980). Maize stemborer (Chilo partellus) is considered as the most destructive pest causing losses up to $75 \%$. Infestations at seedling stage may cause a total failure of the crop (Khan et al. 1999, Rahim and Masud 1992, Sekhon and Kanta 1992). This pest also attacks other grain crops such as sorghum, millets, sugarcane and rice.

The young stem-borer larvae are small, spotted and yellowish. When full grown, they are 20 to $25 \mathrm{~mm}$ long and spotted with coloured stripes along the back of the body. Pupation takes place in the stem in a small chamber. The straw colored moth $(15 \mathrm{~mm})$, deposits white scale like eggs in overlapping rows, usually on the under- side of the leaves (Alejandro 1987). Stem-borer starts to infest the crop at 3 to 4 weeks after planting and continue up to maturity stage (Subasinghe 1988). Larvae which attacks all parts of the maize plants except roots injure the young leaves and later bore into the stem, tassels, stalks and ears of the maize plants (Khan and Amjad 2000). The present recommendations for the management of this pest include foliar spraying of Novaluron 10EC, Thiodicarb 375SC, Etofenprox 10EC or application of granular formulation, Diazinon $5 \mathrm{G}$. However, effective control of the pest cannot be expected from liquid formulations due to practical difficulties in application especially in the advance stages of the crop. On the other hand, Diazinon, the presently recommended granular insecticide for maize stem borer, is a moderately toxic insecticide. Realizing these limitations, experiments were conducted during yala 2008 and yala 2009 to study the efficacy of more safer granular type insecticides against stem borer and to review the efficacy of presently recommended insecticide Diazinon 5G. 


\section{MATERIALS AND METHODS}

The experiment was conducted in two consecutive yala seasons adopting randomized complete block design with 4 replications. Variety "Sampath" was used. Seeds were sowed at a spacing of $60 \times 30 \mathrm{~cm}$ on plots measuring $3.6 \times 3 \mathrm{~m}$. All the cultural practices recommended by the Department of Agriculture were followed. The following insecticides were tested at the given rates (Table 1).

Table 1. Tested insecticides against maize stem borer during yala 2008 and 2009 and their rate of application

\begin{tabular}{|c|c|c|c|c|}
\hline \multirow{3}{*}{ Insecticide formulation } & \multicolumn{4}{|c|}{ Rate of applica-WHO Hazard } \\
\hline & \multicolumn{2}{|c|}{ tion } & \multicolumn{2}{|c|}{ Category } \\
\hline & $(\mathrm{kg} / \mathrm{ha})$ & gai/ha) & a.i. & Formu- \\
\hline Diazinon 5G* & 15 & 750 & II & III \\
\hline Fipronil 0.3G & 12 & 36 & II & IV \\
\hline $\begin{array}{l}\text { Thiocyclam hydrogen } \\
\text { oxalate } 4 \mathrm{G}\end{array}$ & 15 & 600 & II & IV \\
\hline $\begin{array}{l}\text { Thiocyclam hydrogen } \\
\text { oxalate } 4 \mathrm{G}\end{array}$ & 20 & 800 & II & IV \\
\hline Imidacloprid $0.3 \mathrm{G}$ & 10 & 30 & II & IV \\
\hline Imidacloprid $0.3 \mathrm{G}$ & 15 & 45 & II & IV \\
\hline
\end{tabular}

*Recommended insecticide

Insecticides were applied 2 times at 3 and 5 weeks after sowing as whorl application. Percentages of damaged plants were recorded before application of the insecticides and 7 days after first and second applications. Number of stem borer larvae and pupae in 10 randomly selected plant stems was recorded at 8 weeks after planting. Scale developed by Guthrie et al. (1960) has used to estimate the severity of leaf damage (Table 2).
Table 2. Severity scale of leaf feeding damage

\begin{aligned} & \hline Scale \multicolumn{1}{c}{ Damage Severity } \\ & \hline 1 $\begin{array}{l}\text { No visible leaf injury or a small amount of pin } \\ \text { or fine shot hole type injury on a few leaves }\end{array} \\ & 2 \begin{array}{l}\text { Small amount of shot hole type lesions on a } \\ \text { few leaves }\end{array} \\ & 3$ Shot hole injury common on several leaves \\ & 4 Several leaves with shot hole \& elongated \\ & lesions \\ & 5 Several leaves with elongated lesions \\ & 6 $\begin{array}{l}\text { Several leaves with elongated lesions about } \\ 7\end{array} \\ & 7 \begin{array}{l}\text { Long lesions common on about half of the } \\ \text { leaves }\end{array} \\ & 8$ Long lesions common on about $2 / 3$ of leaves \\ & 9 Long lesions in more than $2 / 3$ of leaves \\ & \hline\end{aligned}

Severity index was calculated using the following equation and seed yield was recorded at the harvesting stage.

$\mathrm{P}=$ Severity index $\mathbf{P}=\boldsymbol{\Sigma}(\mathbf{v . n}) / \mathrm{N} . \mathrm{Z} \times \mathbf{1 0 0}$

$\mathrm{v}=$ Score value

$\mathrm{n}=$ Number of plants having same score

$\mathrm{Z}=$ Maximum scale number

$\mathrm{N}=$ Total number of plants observed

\section{RESULTS AND DISCUSSION}

The number of stem borer damaged plants was not significantly different among all the treatments before application of insecticides (Table 3). During yala 2008, at 7 days after first application, the percentage damaged plants due to stem borer in the plots treated with different insecticides varied from 7 to $22 \%$ while the damage in the untreated plots was $29 \%$. At 7 days after second application, the percentage damaged plants in the plots treated with different insecticides varied from 2 to $18 \%$ while the damaged plants in the untreated plot was $40 \%$.

Table 3. Performances of different insecticides on percentage damaged plants during yala 2008 and yala 2009 at Mahailluppallama

\begin{tabular}{|c|c|c|c|c|c|c|}
\hline \multirow{3}{*}{ Treatment } & \multicolumn{6}{|c|}{$\%$ Damaged plants* } \\
\hline & \multicolumn{4}{|c|}{ Yala 2008} & \multicolumn{2}{|c|}{ Yala 2009} \\
\hline & Before app. & $\begin{array}{l}\text { 7days after } \\
1^{\text {st }} \text { app. }\end{array}$ & $\begin{array}{l}7 \text { days after } 2^{r d} \\
\text { app. }\end{array}$ & $\begin{array}{l}\text { Before } \\
\text { app. }\end{array}$ & $\begin{array}{l}\text { 7days after } 1^{\text {st }} \\
\text { app. }\end{array}$ & $\begin{array}{l}7 \text { days after } \\
2^{\text {rd }} \text { app. }\end{array}$ \\
\hline$\overline{\text { Diazinon } 5 \mathrm{G}(15 \mathrm{~kg} / \mathrm{ha})}$ & 16.3 & $7.5 b^{*}$ & $2.9 \mathrm{c}$ & 34.5 & $9.5 \mathrm{c}$ & $5.6 \mathrm{c}$ \\
\hline Fipronil 0.3G (12kg/ha) & 18.3 & $7.9 \mathrm{~b}$ & $3.3 \mathrm{c}$ & 35.6 & $4.5 \mathrm{c}$ & $2.8 \mathrm{c}$ \\
\hline Thio. hy. Ox.4G (15kg/ha) & 18.7 & $14.3 \mathrm{ab}$ & $10.5 b$ & 39.8 & $5.1 \mathrm{c}$ & $7.7 \mathrm{c}$ \\
\hline Thio. hy. Ox.4G (20kg/ha) & 24.1 & $7.7 \mathrm{~b}$ & $2.9 \mathrm{c}$ & 30.5 & $4.1 \mathrm{c}$ & $5.5 \mathrm{c}$ \\
\hline Imidacloprid $0.3 \mathrm{G}(10 \mathrm{~kg} / \mathrm{ha})$ & 21.9 & $13.5 \mathrm{~b}$ & $17.3 \mathrm{~b}$ & 32.0 & $21.4 b$ & $15.9 \mathrm{~b}$ \\
\hline Imidacloprid $0.3 \mathrm{G}(15 \mathrm{~kg} / \mathrm{ha})$ & 27.2 & $21.9 \mathrm{ab}$ & $17.6 \mathrm{~b}$ & 33.5 & $23.4 b$ & $18.5 b$ \\
\hline Untreated Control & 23.7 & $29.3 \mathrm{a}$ & $40.3 \mathrm{a}$ & 40.7 & $47.2 \mathrm{a}$ & $35.4 \mathrm{a}$ \\
\hline $\mathrm{CV} \%$ & ns & 20 & 16 & ns & 28 & 29 \\
\hline
\end{tabular}

*Means in a column followed by the same letters are not significantly different at $5 \%$ level

(analysis based on Arc sin transformed values) ns - not significant 
Table 4. Effect of different insecticides on number of larvae and pupae in 10 plant stems during yala 2008 and 2009 at Mahailluppallama

\begin{tabular}{lcccc}
\hline & \multicolumn{4}{c}{ Larvae + Pupae/ 10 plant stems* } \\
\cline { 2 - 5 } Treatment & \multicolumn{2}{c}{ Yala 2008 } & \multicolumn{2}{c}{ Yala 2009 } \\
\cline { 2 - 5 } & $\begin{array}{c}\text { Larvae }+ \text { Pupae/ } \\
\text { 10 plant stems }\end{array}$ & $\begin{array}{c}\text { \% reduction } \\
\text { over control }\end{array}$ & $\begin{array}{c}\text { Larvae }+ \text { Pupael } \\
\text { 10 plant stems }\end{array}$ & $\begin{array}{c}\text { \% reduction } \\
\text { over control }\end{array}$ \\
\hline Diazinon 5G $(15 \mathrm{~kg} / \mathrm{ha})$ & $3.5 \mathrm{~b}$ & 81 & $16.0 \mathrm{~b}$ & 61 \\
Fipronil 0.3G(12kg/ha) & $1.8 \mathrm{~b}$ & 90 & $10.5 \mathrm{~b}$ & 75 \\
Thio. hy. Ox.4G $(15 \mathrm{~kg} / \mathrm{ha})$ & $9.3 \mathrm{ab}$ & 50 & $23.0 \mathrm{~b}$ & 45 \\
Thio. hy. Ox.4G $(20 \mathrm{~kg} / \mathrm{ha})$ & $3.8 \mathrm{~b}$ & 79 & $17.0 \mathrm{~b}$ & 59 \\
Imidacloprid 0.3G $(10 \mathrm{~kg} / \mathrm{ha})$ & $17.3 \mathrm{a}$ & 6 & $43.0 \mathrm{a}$ & - \\
Imidacloprid 0.3G $(15 \mathrm{~kg} / \mathrm{ha})$ & $13.5 \mathrm{ab}$ & 27 & $42.7 \mathrm{a}$ & - \\
Untreated Control & $18.5 \mathrm{a}$ & - & $42.0 \mathrm{a}$ & - \\
CV\% & 24 & & 31 & \\
\hline
\end{tabular}

*Means in a column followed by the same letters are not significantly different at 5\% level

Table 5. Effect of different insecticides on severity of stem borer damage during yala 2008 and 2009 at Mahailluppallama

\begin{tabular}{lcc}
\hline & \multicolumn{2}{c}{ Severity Index* } \\
\cline { 3 - 3 } Treatment & Yala 2008 & Yala 2009 \\
\hline Diazinon 5G $(15 \mathrm{~kg} / \mathrm{ha})$ & $11.6 \mathrm{~d}$ & $25.0 \mathrm{de}$ \\
Fipronil 0.3G $(12 \mathrm{~kg} / \mathrm{ha})$ & $11.6 \mathrm{~d}$ & $14.8 \mathrm{e}$ \\
Thio. hy. Ox. 4G $(15 \mathrm{~kg} / \mathrm{ha})$ & $12.0 \mathrm{~d}$ & $26.8 \mathrm{~cd}$ \\
Thio. hy. Ox. 4G $(20 \mathrm{~kg} / \mathrm{ha})$ & $15.3 \mathrm{~d}$ & $22.9 \mathrm{de}$ \\
Imidacloprid 0.3G $(10 \mathrm{~kg} / \mathrm{ha})$ & $27.1 \mathrm{c}$ & $43.0 \mathrm{ab}$ \\
Imidacloprid 0.3G $(15 \mathrm{~kg} / \mathrm{ha})$ & $33.1 \mathrm{~b}$ & $36.3 \mathrm{bc}$ \\
Control & $55.1 \mathrm{a}$ & $47.6 \mathrm{a}$ \\
CV\% & 16 & 21 \\
\hline
\end{tabular}

*Means in a column followed by the same letters are not significantly different at 5\% level

The lowest damage was recorded in the plots treated with Diazinon 5G followed by Fipronil $0.3 \mathrm{G}$ and Thiocyclam hydrogen oxalate $4 \mathrm{G}$ (80ga.i./ha). During yala 2009, at 7 days after first and second application, number of damaged plants were significantly low in Diazinon $5 \mathrm{G}$, Fipronil $0.3 \mathrm{G}$ and Thiocyclam hydrogen oxalate $4 \mathrm{G}(800 \mathrm{~g}$ a.i./ha) treated plots.

The larval and pupal population in 10 plant stems was significantly low in Diazinon, Fipronil and Thiocyclam hydrogen oxalate (800ga.i./ha) treated plots compared to that of the untreated control plot during both seasons (Table 4). The percentage reduction of stem borer population ranged from $79-90 \%$ and 59 $75 \%$ in these three insecticide treated plots over the control plot during yala 2008 and yala 2009 respectively.

The severity of stem borer damage during yala 2008 was significantly low in all the insecticide treated plots compared to the untreated plot (Table 5). Diazinon, Fipronil and Thiocyclam
Table 6. Effect of different insecticides on seed yield of maize during yala 2008 and 2009 at Mahailluppallama

\begin{tabular}{|c|c|c|c|c|}
\hline \multirow[b]{2}{*}{ Treatment } & \multicolumn{2}{|c|}{ Yala 2008} & \multicolumn{2}{|c|}{ Yala 2009} \\
\hline & $\begin{array}{l}\text { Seed } \\
\text { yield } \\
(t / h a)\end{array}$ & $\begin{array}{l}\text { \% yield } \\
\text { increase } \\
\text { over the } \\
\text { control }\end{array}$ & $\begin{array}{l}\text { Seed } \\
\text { yield } \\
(t / h a)\end{array}$ & $\begin{array}{l}\text { \% yield } \\
\text { increase } \\
\text { over the } \\
\text { control }\end{array}$ \\
\hline $\begin{array}{l}\text { Diazinon 5G } \\
(15 \mathrm{~kg} / \mathrm{ha})\end{array}$ & $3.8 a^{*}$ & 65 & $4.6 \mathrm{ab}$ & 28 \\
\hline $\begin{array}{l}\text { Fipronil } 0.3 \mathrm{G} \\
(12 \mathrm{~kg} / \mathrm{ha})\end{array}$ & $4.4 \mathrm{a}$ & 91 & $5.2 \mathrm{a}$ & 44 \\
\hline $\begin{array}{l}\text { Thio. hy. Ox. } 4 \mathrm{G} \\
\text { (15kg/ha) }\end{array}$ & $3.3 \mathrm{ab}$ & 43 & $4.4 b$ & 22 \\
\hline $\begin{array}{l}\text { Thio. hy. Ox. } 4 \mathrm{G} \\
(20 \mathrm{~kg} / \mathrm{ha})\end{array}$ & $3.5 \mathrm{ab}$ & 52 & $4.6 \mathrm{ab}$ & 28 \\
\hline $\begin{array}{l}\text { Imidacloprid } 0.3 \mathrm{G} \\
(10 \mathrm{~kg} / \mathrm{ha})\end{array}$ & $2.5 \mathrm{c}$ & 9 & $3.7 \mathrm{c}$ & 3 \\
\hline $\begin{array}{l}\text { Imidacloprid } 0.3 \mathrm{G} \\
(15 \mathrm{~kg} / \mathrm{ha})\end{array}$ & $2.6 \mathrm{bc}$ & 13 & $3.3 \mathrm{c}$ & - \\
\hline Control & $2.3 \mathrm{c}$ & - & $3.6 \mathrm{c}$ & - \\
\hline CV\% & 23 & & 14 & \\
\hline
\end{tabular}

*Means in a column followed by the same letters are not significantly different at 5\% level

hydrogen oxalate found to be superior in reducing stem borer damage during both seasons.

Diazinon, Fipronil and Thiocyclam treated plots gave significantly higher yields than the control plot during both seasons. Yields in Diazinon, Fipronil and Thiocyclam hydrogen oxalate $(800 \mathrm{ga} . \mathrm{i} . / \mathrm{ha})$ treated plots found to be 52$91 \%$ and $28-44 \%$ higher compared to the control during yala 2008 and yala 2009 respectively (Table 6).

\section{CONCLUSION}

Among the different granular insecticides (Diazinon 5G, Fipronil 0.3G, Thiocyclam hydrogen Oxalate $4 \mathrm{G}$, Imidacloprid $0.3 \mathrm{G}$ ) evalu- 
ated Fipronil 0.3G (@12kg/ha) and Thiocyclam hydrogen oxalate 4G (@20 kg/ha) found to be significantly superior in controlling maize stem borer damage. Hence, whorl application of these two granular insecticides can be suggested for effective management of stem borer infestation in maize.

\section{REFERENCES}

AgStat 2009 Pocket book of Agricultural Statistics. Volume VI. Socio-Economic and Planning Centre, Department of Agriculture, Peradeniya, Sri Lanka. pp. 59.

Alejandro OC 1987 Insect Pests of Maize. A guide for field identification. International Maize and Wheat Improvement Center, Mexico. pp.106.

Guthrie WD, Dicke FF and Neiswander CR 1960 Leaf and sheath feeding resistance to the European corn borer in eight inbred lines of dent corn. Ohio. Agricultural Experiment Station Research Bulletin. 860:

Hindagala CBA 1980 Varietal improvement and

\section{CONTROL OF MAIZE STEM-BORER}

agronomic studies of maize (Zea mays L.) in the dry zone. Trop. Agric. 136: 119-134.

Khan MA, Khan AH, Ahmad K and Baloch MS 1999 Control of stem borer by different insecticides in corn hybrid 4208. Pakistan Journal of Biological Sciences 2(3):612-613.

Khan SM and Amjad M 2000 Chemical control of maize stem borer (Chilo partellus Swin.). Pakistan Journal of. Biological Sciences 3(12): 21162118.

Rahim A and Masud SA 1992 Efficacy of synthetic pesticides on shootfly Atherigona soccata (Rondani) and maize borer Chilo partellus (swinhoe) in Sada Bahar and effect on yield. Sarhad Journal of Agriculture 8: 205-208.

Sekhon SS and Kanta U 1992 Effect of seed treatment and other insecticidal formulations on the control of maize borer, Chilo partellus (swinhoe). Journal of Insect Science 5:45-47.

Subasinghe SMC and Amarasena J 1988 Temporal distribution and chemical control of the maize stem borer, Chilo partellus swinhoe (Lep.; Pyralidae). Trop. Agric. 144: 123-133. 